\title{
Artisan Brick Kilns: State-of-the-Art and Future Trends
}

\author{
Hugo Valdes ${ }^{1, *}{ }^{\mathbb{D}}$, Juan Vilches ${ }^{2}$, Gabriel Felmer ${ }^{3} \mathbb{C}$, Mariela Hurtado ${ }^{4}$ and Juan Figueroa ${ }^{2}(\mathbb{D}$ \\ 1 Departamento de Computación e Industrias, Centro de Innovación en Ingeniería Aplicada, \\ Universidad Católica del Maule, Talca 3460000, Chile \\ 2 Departamento de Obras Civiles, Centro de Innovación en Ingeniería Aplicada, \\ Universidad Católica del Maule, Talca 3460000, Chile; jvilches@ucm.cl (J.V.); jfiguero@ucm.cl (J.F.) \\ 3 Instituto de la Vivienda, Facultad de Arquitectura y Urbanismo, Universidad de Chile, Santiago 8320000, \\ Chile; gefelmer@gmail.com \\ 4 Departamento de Obras Civiles, Escuela de Ingeniería Civil, Universidad Católica del Maule, \\ Talca 3460000, Chile; mariela.hurtado@alu.ucm.cl \\ * Correspondence: hvaldes@ucm.cl; Tel.: +56-2-71-2203100
}

Received: 29 August 2020; Accepted: 15 September 2020; Published: 18 September 2020

check for updates

\begin{abstract}
A large part of the global brick manufacturing industry has evolved based on knowledge transmitted from generation to generation without developing a consistent scientific approach. The purpose of this article is to contribute to this approach by discussing the state-of-the-art and future trends of the design and construction of artisan brick kilns (ABK). The methodology proposed for this study is based on a systematic literature review whereby main question is: What research exists on brick kilns? Based on the results of this review, it is recommended that appropriate emerging technologies that should be incorporated to ABKs for either medium or small enterprises should be: mechanical fans, envelope thermal insulation, organic waste of uniform size as fuel, automatic control of process variables and computer simulations of phenomenological processes. This should be accompanied by technical training for the brick-makers and greater access to financing funds. The technologies reviewed throughout the paper will allow for a more thermally efficient design of kilns, which will emit less hazardous greenhouse gases and atmospheric pollutants.
\end{abstract}

Keywords: artisan brick kiln; brick kiln emissions; energy efficiency; clean combustion; sustainable energy

\section{Introduction}

In recent years, improvements in living standards, sustained technological development and increased demand for new infrastructure have led to significant growth in the consumption of construction materials. The construction industry uses raw materials by weight more than any other industrial sector [1]. About 50\% of all materials extracted from the Earth's crust are processed into construction materials [2]. The building materials are classified as: structural clay products (bricks), rock and stones, wood and wood products, concrete, aggregates, water, lime, pozzolans, building mortars, ferrous and non-ferrous metals, ceramic materials, polymeric materials, paints, enamels, varnishes, tar, bitumen, asphalt, gypsum, adhesives, heat-insulating materials and sound-insulating materials. One of the oldest building materials, brick, continues to be one of the most popular and leading construction materials because it is cheap, durable and easy to handle and work with. Clay bricks are used for building up exterior and interior walls, partitions, piers, footings and other load-bearing structures [3].

The brick industry is the oldest industry in the history of mankind; it can be said that it is the only manmade material that has defied time even though it was invented 5000 years ago [4]. Asia produces 
1300 billion bricks annually, making it the world's largest producer of bricks. China, India, Pakistan and Vietnam account for $67 \%, 13 \%, 3 \%$ and $1.7 \%$ of the world's brick production, respectively [5]. The Indian brick sector consumes more than 24 Mton of coal annually along with huge quantity of biomass fuels [6]. On the other hand, Swisscontact [7] reports that: (1) in Latin America there are approximately 41,000 brick producers, with a high heterogeneity of production levels, technology and profitability, among the countries and within the same countries; (2) the countries with low technological levels are Ecuador, Argentine, Mexico, Chile and Central American countries, which is also reflected in the low levels of kiln capacities, while Brazil (technological leader in Latin America) and Colombia have production areas with technology ranging from semi-mechanized brick kilns (BKs) to fully automated production units and high efficiency kilns; (3) Peru and Bolivia have a mix of business clusters, where some of these have implemented certain technologies and others have all their production based on manual processes (local traditions); (4) it is estimated that in Peru, Bolivia, Brazil and Mexico there are 2500, 3000, 7000 and 17,000 brick kilns, respectively; and (5) about $40 \%-50 \%$ of Latin America's brick production comes from artisanal brick kiln (ABK), e.g., using open kilns (old rural building), low efficiency and high emissions without any control. These ABKs are small production units, highly dispersed and difficult to oversee. The artisanal firing process varies according to geographical location and material available in the manufacturing area, and it is a process that is based on tradition and folklore more than on a basis justified by studies or scientific analysis.

The conventional brick kilns are not energy efficient and the emissions from the brickfields are severely contaminating the environment [8]. The artisan brick production sector needs exploratory research at a global level, such as that set out in this manuscript, as most of the research of ABKs are case studies, although there are some coincidences in the process shortcomings. Swisscontact [7] has identified the most relevant problems of the Latin American artisanal brick industry: (1) scarce or no regulation and/or lack of enforcing laws (emissions, land use planning, product quality, occupational health, child labor, etc.), (2) lack of clarity and security in land use planning, (3) invisibility of the sector for the public sector, (4) lack of knowledge of the impact on health and climate, as well as the costs related to these impacts, (5) limited access to financing, (6) lack of information on the availability and profitability of low-emission technology, (7) scarce options for the transitional move from "artisanal" to "mechanized," (8) need to develop studies for reference scenarios of the brick sector, both on the financial and emissions levels involving current and expected expectations and technologies, (9) lack of sector capacities in business management and productivity, (10) high informality, (11) bureaucratic difficulties in obtaining licenses and (12) the lack of involvement from the construction sector for the demand of more sustainable products.

The information presented in this manuscript allows to visualize the problems of the brick industry. In addition, this research is to provide a systematic review of recently published scientific work about ABKs. A critical analysis is reported about types of BKs, fuels used, emissions of polluting gases, negative effects of pollutants, phenomenological studies about firing process and future trends for ABKs.

\section{Methods}

This article is based on an informational systematic review. This methodology is a rigorous review, which was originally developed mainly within medical research and first outlined for the field of organization and management studies by Tranfield [9]. Systematic reviews exhibit significant advantages compared to traditional narrative approaches of literature reviews. Said reviews generally do not follow a formal methodology, thus resulting in a lack of transparency and replicability by others [10]. The principal search question was: What research exists on brick kilns?

A large proportion of information about ABK is available in manuals and technical reports. Therefore, this technical information complements the information not found in scientific articles.

This review paper attempted to review the published papers in various application areas related to BK. Therefore, this paper aimed to identify the papers related to BK in various parts of the published 
papers such as keywords, title, research method, results, conclusions and discussions. In relation to the classification scheme, a reference repository has been established, which included papers in international scholar journals from 2013 to 2019. The target databases for this paper were "Scopus" and "Web of Science" as the two important databases which cover the extensive range of journal scopes. The articles were categorized based on the application areas, publication year, journal name, study purpose and type of study (utilized, proposed, integrated, modified or extended types). This present article, first, classified articles into five fields (kilns types, emissions, fuels, energy efficiency and phenomenology); secondly, analyzed the study type; and third, reviewed articles based on research purpose and goal.

\section{State of the Art of Brick Kilns}

Figure 1 shows the search done in the Web of Science (WoS) and Scopus platforms, using the topic "brick kiln." The number of articles indexed in Scopus are greater than in WoS. The total number of items in this time-period was 582 and 1452 for WoS and Scopus, respectively. This research analyzed the period between 2013 and 2019, which represents 53\% and 34\% of the articles found in WoS and Scopus, respectively.

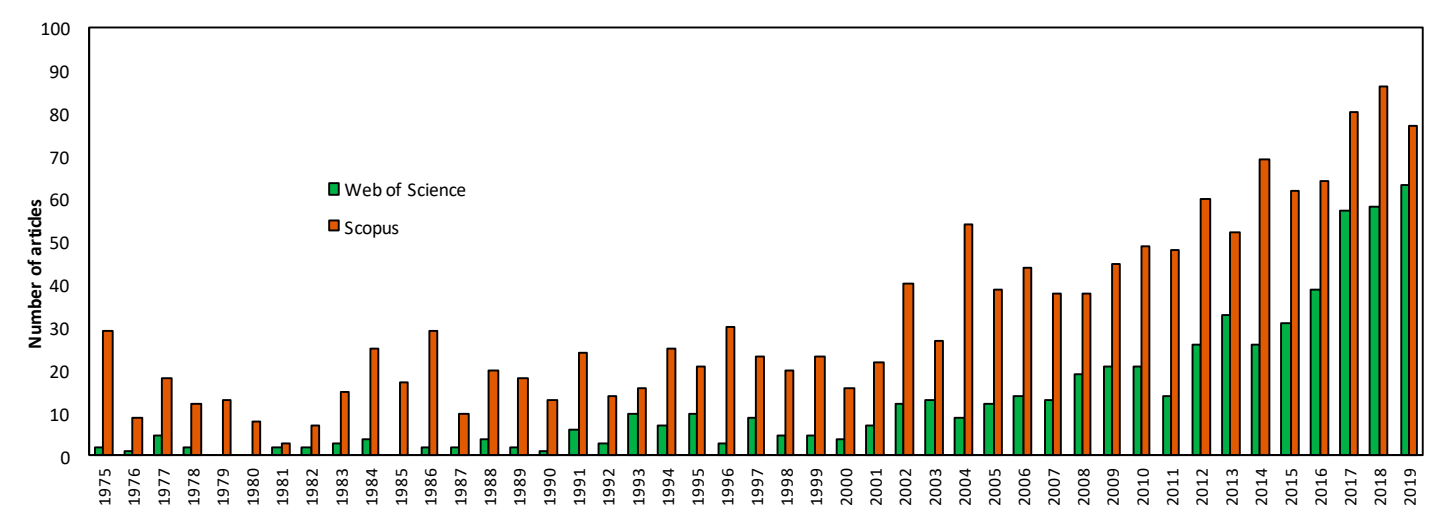

Figure 1. Graph of the number of scientific articles indexed in Web of Science (WoS) and Scopus for the topic "brick kiln" (1975 to 2019).

Using the exact topic "brick kiln" between 2013-2019, 98 and 233 documents in WoS and Scopus were found, respectively. These articles are divided into various topics: emissions (36\%), pollutant $(26 \%)$, efficiency $(13 \%)$, biomass $(13 \%)$ and design (12\%). Figure 2 shows that the main authors researching "brick kiln" have affiliations in Pakistan and United States. The main authors focused their research on pollution caused by brick making. e.g., Kamal et al. [11] evaluated the health risks of BK workers to dust-bound polycyclic aromatic hydrocarbons (PAHs) exposure in Punjab province (Pakistan). This study also emphasized the need for pollution control in the BK industry of Pakistan. Kamal et al. [12] evaluated the atmospheric concentration levels and ambient exposure of PAHs in Gujranwala, Lahore and Rawalpindi districts of the Punjab Province (Pakistan). Results also showed that $\sim 88 \%$ of the atmospheric PAHs could be attributed to the wood combustions, out of which more than $50 \%$ of wood combustion were possible with the BK sector. 


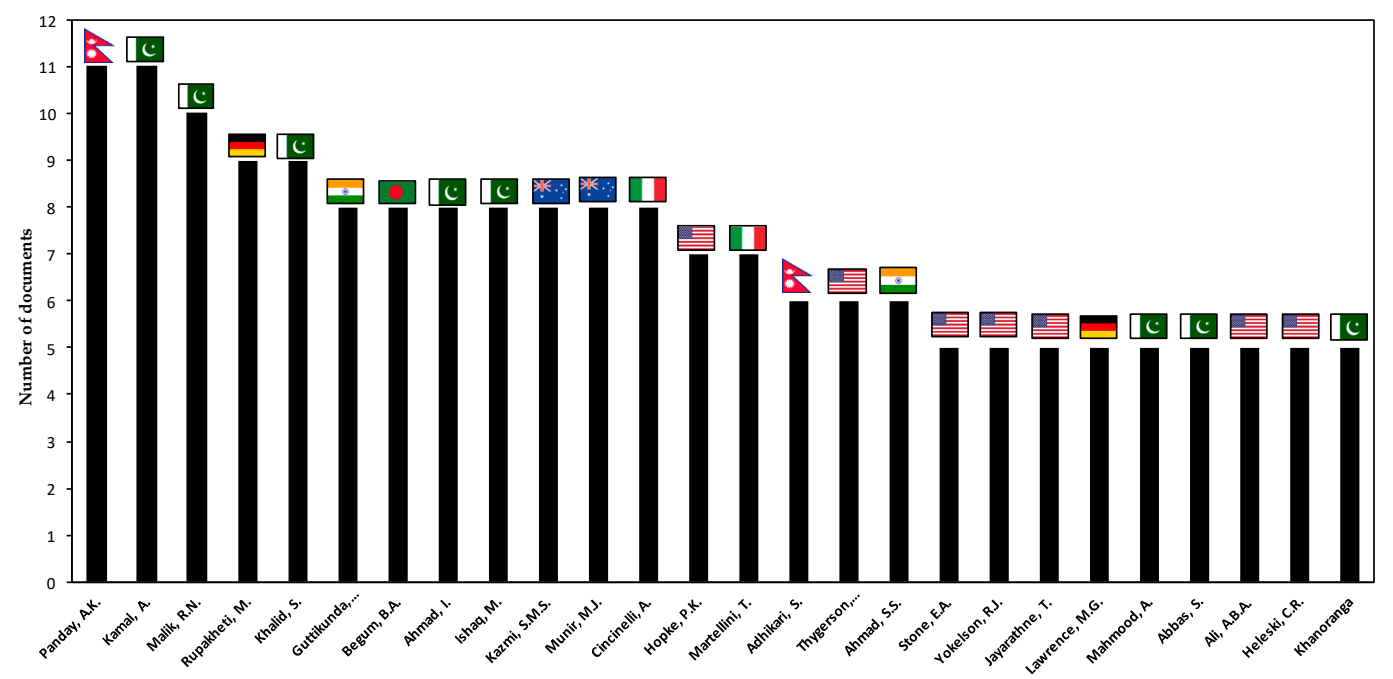

Figure 2. Graph of the main authors (WoS + Scopus) with the exact topic "brick kiln" (2013-2019).

Figure 3 shows that the first BK patent was in 1890 and the important BK research milestones were achieved from 1975 to 2019. Currently, the impact of the BK industry on the environment and human health is being evaluated, together with the trend towards making bricks with more energy-efficient processes. This leads to lower pollutant emissions, improved fuel quality and reduced fuel consumption. In this context, the systematic review allowed to divide the state of the art of artisan brick kilns into (1) types of furnaces, (2) emissions, (3) fuels, (4) energy efficiency and (5) phenomenology.

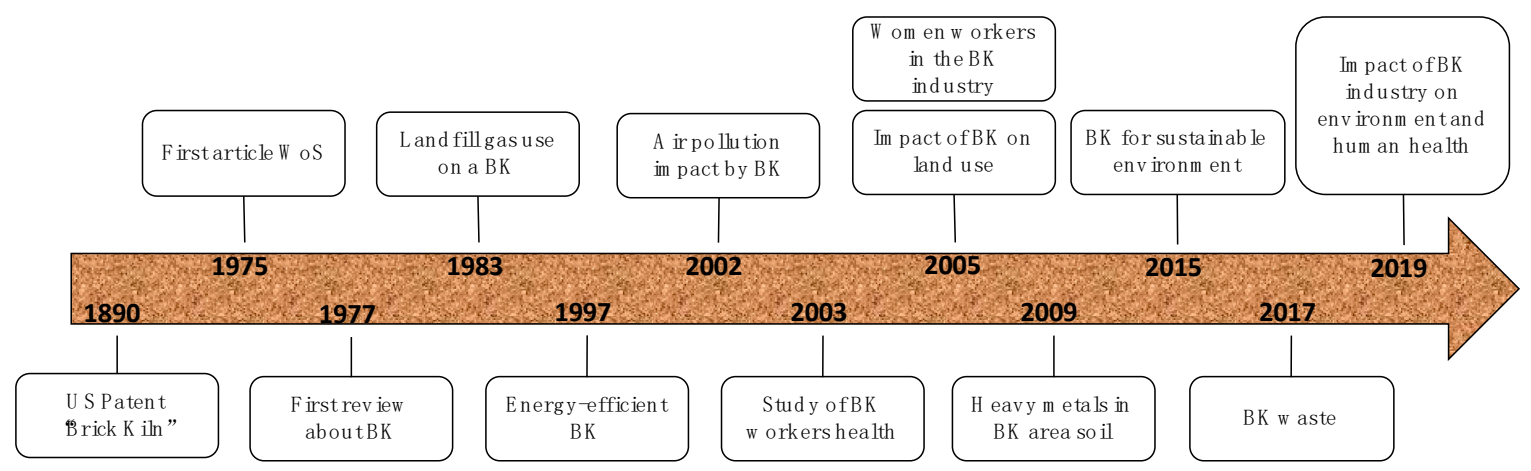

Figure 3. Diagram of important milestones in the history of the brick kiln (BK) [8,13-24].

\subsection{Brick Kiln Types}

Figure 4 shows some BK types according to their operation mode and flow type. Several authors classify BKs into intermittent and continuous [5,15,25]. In intermittent kilns, bricks are fired and cooled in batches. The kiln must be emptied and refilled, and a new fire has to be started for each batch of bricks. Most of the heat contained in the hot flue gases, fired bricks and the kiln structure is thus lost. Intermittent kilns are widely used in several countries of Asia, Africa and Latin America. Intermittent kilns can be further subdivided into without chimney (open kiln) and with chimney (i.e., down-draft and climbing kiln). In a continuous kiln, the fire is always burning and bricks are being warmed, fired and cooled simultaneously in different parts of the kiln. Fired bricks are continuously removed and green bricks are continuously added. Consequently, the rate of output is almost constant. Heat in the flue gas is used to heat and dry green bricks, and the heat in the fired bricks is used to preheat air for combustion. Due to the incorporation of heat recovery features, continuous kilns are more energy-efficient than intermittent kilns [25]. Continuous kilns can be further subdivided into moving fire kilns and moving ware kilns. On the other hand, there are at least ten processes associated 
with the operation type of the BK: (a) open kiln (e.g., campaign, "caiera," volcano), (b) dormant fire, (c) open kiln with fixed walls (e.g., scotch, arab, fixed wall with fixed combustion chamber, with armed chamber for each burn, squares and caipira (Brazil)), (d) simple downdraft, (e) Marquez kiln (MK), (f) dome (e.g., beehive), (g) Hoffman, (h) Bull's Trench, (i) cedan, (j) multi-chamber, (k) zig-zag, (l) mobile-modular, (m) vertical continuous and (n) tunnel (Figure 5).

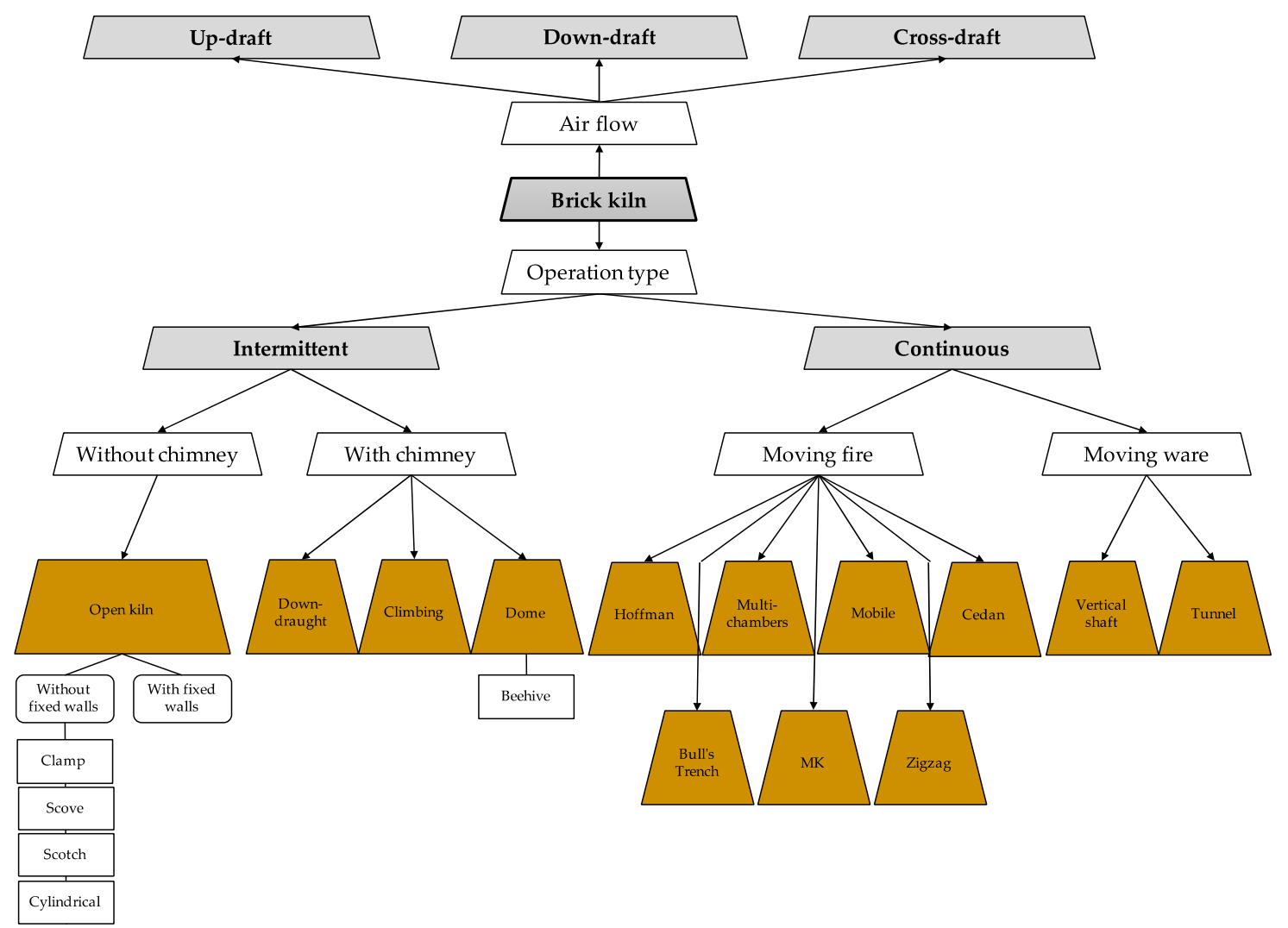

Figure 4. Classification diagram of the BKs.

Table 1 shows indicators of the brick manufacturing process according to BK type. The quality of the brick depends on BK type, i.e., the kilns: open, dormant fire and open with fixed walls have $<40 \%$ of top quality pieces, while the kilns: Hoffman, multi-chamber, cedan, mobile, vertical continuous and tunnel have over $80 \%$ of top quality pieces [7,26-28]. The tunnel kiln is the BK with the highest level of investment (>US $\$ 200,000$ ), but at the same time, it allows for greater production capacity (200,000 brick/week), greater energy efficiency $(<2 \mathrm{MJ} / \mathrm{kg}$ ), more than $80 \%$ of high quality parts and lower particulate emissions $\left(<250 \mathrm{mg} / \mathrm{Nm}^{3}\right)$ [7]. 


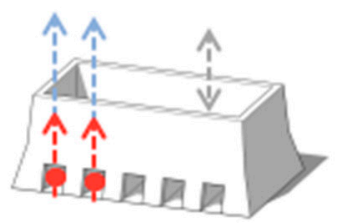

(a)

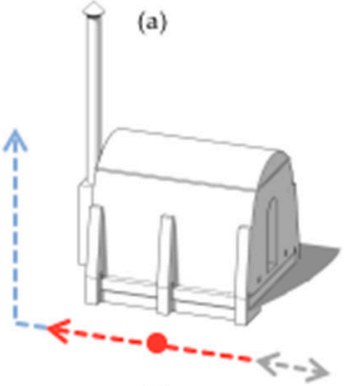

(d)

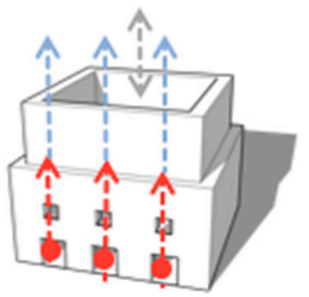

(b)

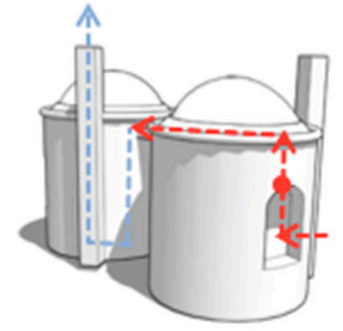

(e)

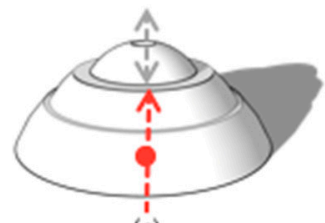

(c)

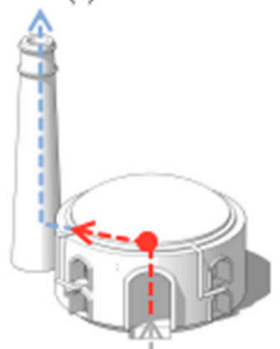

(f)

$\rightarrow$ pre-heating zone

$\rightarrow->$ firing zone

- $>$ cooling zone

$\cdots>$ exhaust flow

- $\rightarrow$ brick loading

(-) brick unloading

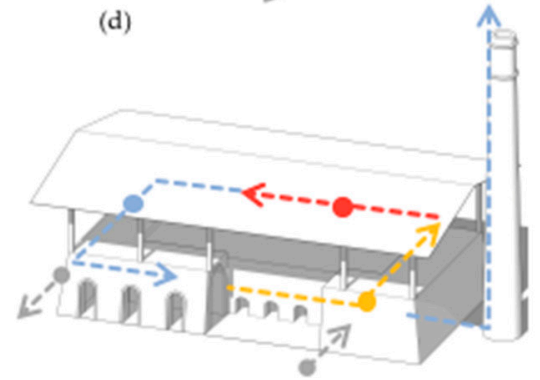

(g)
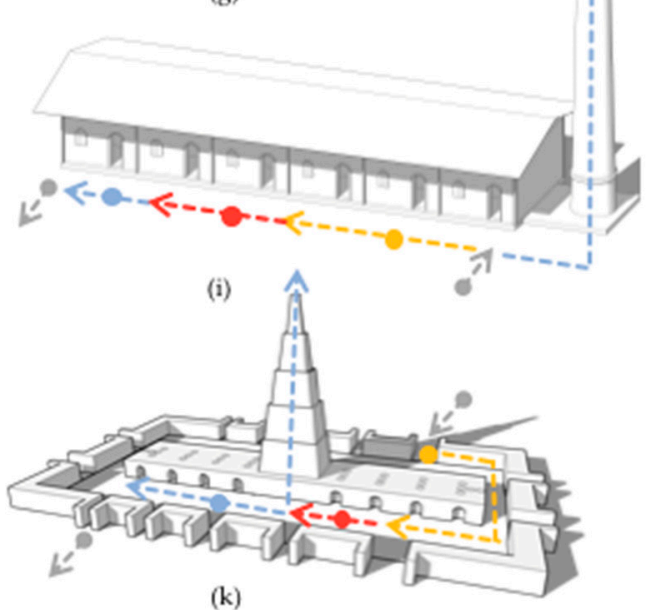

(k)

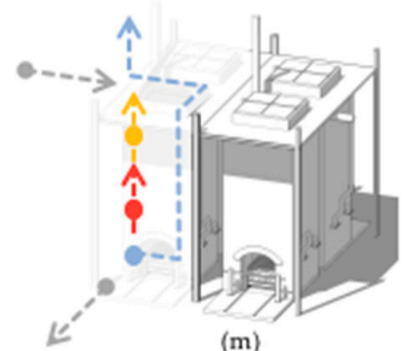

(m)

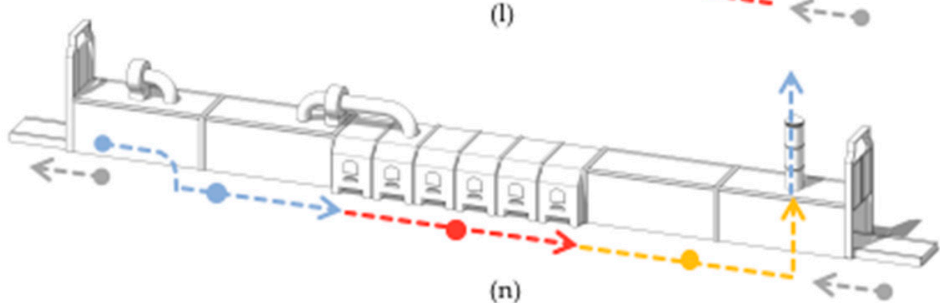

(n)

Figure 5. Drawings of the intermittent and continuous ovens. The arrows indicate the flow of brick loads and gas flow. (a) Open kiln without fixed walls (rectangular), (b) open kiln with fixed walls, (c) open kiln without fixed walls (cylindrical), (d) down-draught, (e) MK, (f) dome, (g) Hoffman, (h) Bull's Trench, (i) Cedan, (j) multi-chambers, (k) zigzag, (1) mobile-modular, (m) vertical shaft and (n) tunnel. 
Table 1. Summary of typical ranges of environmental, economic and production parameters for BKs. Information compiled by the authors.

\begin{tabular}{|c|c|c|c|c|c|c|c|}
\hline \multirow{2}{*}{ Kiln Type } & $\begin{array}{l}\text { Investment } \\
\text { Level }\end{array}$ & $\begin{array}{l}\text { Production } \\
\text { Capacity }\end{array}$ & $\begin{array}{c}\text { Energy } \\
\text { Consumption }\end{array}$ & $\begin{array}{l}\text { Thermal } \\
\text { Efficiency }\end{array}$ & PM Emissions & $\begin{array}{c}\mathrm{CO}_{2} \\
\text { Emissions }\end{array}$ & \multirow{2}{*}{ e.g., Country } \\
\hline & (Miles US \$) & (Miles/Batch) & $\begin{array}{l}\text { (MJ/kg of } \\
\text { Product) }\end{array}$ & $(\%)$ & $\left(\mathrm{mg} / \mathrm{Nm}^{3}\right)$ & $\begin{array}{c}(\mathrm{g} / \mathrm{kg} \text { of } \\
\text { Fired Brick) }\end{array}$ & \\
\hline $\begin{array}{l}\text { Open kiln without fixed } \\
\text { walls (rectangular) }\end{array}$ & $1-10$ & $<60$ & $3.5-5.5$ & $10-20$ & $>500$ (soot presence) & $>400$ & Chile [29]; Peru [30]; Mexico [31] \\
\hline Open kiln with fixed walls & $2-20$ & $20-60$ & $3.0-5.0$ & $20-30$ & $>500$ (soot presence) & $325-375$ & Indonesia [32]; Mexico [33]; Scotland [34] \\
\hline $\begin{array}{l}\text { Open kiln without fixed } \\
\text { walls (cylindrical) }\end{array}$ & $2-15$ & $<60$ & $3.0-5.0$ & $10-20$ & >500 (soot presence) & $>400$ & Colombia [35]; Peru [36]; Colombia [37] \\
\hline Down-draught & $<30$ & $<60$ & $2.0-4.0$ & $35-45$ & $250-600$ & 250-300 & Bangladesh [38]; Indonesia [39]; India [40] \\
\hline MK & $>100$ & $5-120$ & $2.0-2.5$ & $60-70$ & 100-150 & $60-150$ & Mexico [41]; Bolivia [42] \\
\hline Dome & $30-200$ & $60-200$ & $2.0-4.0$ & $35-45$ & $<250$ & 250-300 & Brazil [43]; Taiwán [44]; Colombia [45] \\
\hline Hoffman & $30-200$ & $60-200$ & $2.0-4.0$ & $45-55$ & $250-600$ & 100-130 & Malaysia [8]; Brazil [46]; Poland [47] \\
\hline Bull's Trench & $>300$ & $30-200$ & $1.0-1.5$ & $50-60$ & $125-600$ & $120-300$ & India [48]; South and South-East Asia [49] \\
\hline Cedan & $>200$ & $>200$ & $1.0-2.0$ & $50-60$ & $<250$ & 165-185 & Brazil [50] \\
\hline Zigzag & $>300$ & $100-200$ & $1.0-1.2$ & $50-60$ & $70-500$ & $90-110$ & India [48]; Nepal [51] \\
\hline Multi-chambers & $30-200$ & $<60$ & $2.0-4.0$ & $50-60$ & $<250$ & 210-300 & Peru [52]; Egypt [53]; Colombia [54] \\
\hline Mobile (modular) & $>200$ & $50-200$ & $1.0-2.0$ & $55-65$ & $<250$ & $160-180$ & Rusia [55]; Brazil, Peru, Bolivia \& Paraguay [26] \\
\hline Vertical shaft & $30-200$ & $60-200$ & $0.8-1.5$ & $70-80$ & $<250$ & $60-90$ & India [40]; China [56]; Macedonia [57] \\
\hline Tunnel & $>200$ & $>200$ & $1.5-2$ & $60-70$ & $<250$ & 150-170 & Egypt [58]; Kuwait [59]; Brazil [60] \\
\hline
\end{tabular}


Future Trends for BK Type

The artisan brick sector is in a period that must adopt efficient technologies and production practices. This sector requires a comprehensive approach. Brick producers must be aware of the benefits that technological change would bring beyond regulatory compliance. The use of validated technologies and low emission practices depend on having this type of technology available in the market: where, the brick producers are the demand for this technology, while the supply is technology suppliers, consultants and financial institutions. Thus, in order to achieve the transition from the artisanal to the mechanized, programs with favorable credit conditions for the producer must be promoted. Therefore, validated information on low-cost technologies with a rapid return on investment must be generated in order to show producers the profitability of the proposed technologies. Examples of successful models are needed, that pass on the experience of early innovators and encourage others to implement change.

Nowadays, a new BK should consider (1) a long fire zone to allow almost complete combustion and fuel efficiency, (2) roof, since it implies significant economic and workforce benefits, (3) low chimney to minimize fuel waste, (4) scalability in both continuous or semi-continuous mode and (5) easy implementation of mechanization. There are several companies that propose innovative designs of brick kilns, e.g., Hzzk's design [61] proposes a long fire zone that accelerates the pre-drying of "green bricks" before full firing and enables faster fire progression, increases brick production and energy efficiency. This long fire zone assisted by a small fan within the kiln creates a unique induced draught, enabling even heat distribution, maximum heat generation and maximum energy extraction from fuel sources. The fire, controlled through the use of unique HZZK internal kiln components, is pulled through stationary bricks placed in a zigzag fashion. This control fire (1) provides consistent quality bricks with even cure and brick shrinkage, (2) enables less than $2 \%$ fired brick waste and (3) due to the excellent control of the fire and the low brick setting height, it is ideally suited to fire perforated bricks and thin walled hollow large clay blocks; this conserves top soil, minimizes land degradation and reduces energy requirements for the production of bricks and clay products. On the other hand, the roof (1) protects kiln workers from all types of weather so that working conditions are improved both day and night and during all seasons, (2) allows for the brick-making season to be extended into the monsoon season, thus increasing annual brick production, (3) overcomes the high 'overlooked costs' of drying out a wet kiln after every winter season, (4) allows for water collection (drinking and sanitation) and (5) allows solar panels to be mounted on the roof, supplying power for the fan and lighting. Moreover, a low chimney is not needed as draught is created by induced draught fan and the emissions are low. Thus, (1) the construction time and construction costs are low, (2) exhaust gases are minimized through almost complete fuel combustion and (3) minimal emissions are released via small chimney made of metal or brick extending just above the roof line. HZZK's design considers brick production requirements (output demand) that determines the size/footprint of the kiln and an increase or decrease in the number of kiln chambers. Options exist to operate in both a continuous or semi-continuous mode, allowing for smaller or larger outputs depending on the operator's requirements i.e., large scale (industrial) or small scale (village/rural setting). Finally, the mechanization/machine automation systems reduce handling of bricks and reduces risk of associated damage. Automatic fuel feeders can be incorporated into the kiln design, providing mechanized fuel distribution.

Trends in new brick kiln designs aim to improve the tunnel kiln as it is the most efficient kiln type $[59,62,63]$. They are composed of a collection of attached opposite directed heat exchangers with the solids on the kiln car that move counter-current with the air flow. There are three main temperature zones in the kiln: preheating, firing and cooling zone. Tunnel kilns are long structure kilns in which the green products are heated up in the preheating zone, and then to the sintering temperature, which is different from one product to another. After that, the product goes through the cooling zone, where it is cooled down to a temperature near the ambient temperature [58]. 


\subsection{BK Emissions}

Several studies about the manufacture of handmade bricks show that pollutant gases are emitted such as $\mathrm{SOx}, \mathrm{NOx}, \mathrm{CO}, \mathrm{CO}_{2}$, particulate matter (PM) or total suspended particulates (TSP)—particles that pass through a size-selective inlet with a 50\% cut-off at 1,2.5 and $10 \mu \mathrm{m}$ aerodynamic diameter $\left(\mathrm{PM}_{1}, \mathrm{PM}_{2.5}\right.$ and $\mathrm{PM}_{10}$, respectively) - metals $(\mathrm{Cu}, \mathrm{Cr}, \mathrm{Pb}, \mathrm{Ni}, \mathrm{Zn}, \mathrm{Cd}, \mathrm{Fe}, \mathrm{Mn})$, fluorides and organic compounds (methane, ethane, volatile organic compounds (VOCs)), persistent organic compounds (POPs) and some hazardous air pollutants such as hydrogen chloride $(\mathrm{HCl})$ and hydrogen cyanide (HCN) [64-69]. Akinshipe and Kornelius [69] reported that the contribution of brick production to global emissions of black carbon, organic carbon, $\mathrm{PM}_{1}, \mathrm{SO}_{2}$ and $\mathrm{CO}$ is $5.5 \%, 2.6 \%, 1.6 \%, 2.9 \%$ and $1.6 \%$, respectively. Meanwhile, the contribution of South-West-Central Asia's brick production to regional emissions of black carbon is $10.4 \%$, e.g., the total emissions from the brick manufacturing in the Greater Dhaka region, to produce 3.5 billion bricks per year has been estimated about 23,300 $\mathrm{t}$ of $\mathrm{PM}_{2.5}, 15,500 \mathrm{t}$ of $\mathrm{SO}_{2}, 302,000 \mathrm{t}$ of $\mathrm{CO}, 6000 \mathrm{t}$ of black carbon and 1.8 million of $\mathrm{CO}_{2}$ [67].

The small particle size of pollutants promotes respiratory diseases [70-73], along with causing environmental stress to plant species $[67,74,75]$. Therefore, investments aimed at new technologies for reducing emissions are fully justified.

The main technological causes of these pollutant emissions are (1) the nature of the fuel and (2) poor air circulation inside the BK. Febres [76] reports that used tires are frequently used in Peruvian ABKs, due to the low cost and shorter cooking time, which according to operators is almost three times less than with charcoal. ABKs use inefficient burning technology that generates substantial air pollution due to the market in which they are exposed. Luby et al. [65] reported that for the brick buyers, the bricks manufactured in ABK worked well for most construction purposes and cost $40 \%$ less than bricks manufactured in more modern, less polluting, kilns. BK owners favored approaches with rapid high returns on a modest investment. They preferred kilns that operate only during the dry season, allowing them to use cheaper, low-lying flood plain land and inexpensive seasonal labor. Many BK violate environmental regulations but shortages of equipment and man-power combined with the kiln owner's political connections, undermine law enforcement. The brick manufacturing system is an economic equilibrium with the manufacture of inexpensive bricks, supplying the demand for construction materials but at a high cost to the environment and the population's health. Akinshipe and Kornelius [69] made a ranking of brick kiln technologies based on available emission metrics. The technologies were then ranked in order of their potential for atmospheric emissions, from least contaminating to most contaminiating: (1) Vertical shaft brick kiln, (2) Zigzag kiln, (3) US coal-fired kiln, (4) Clamp kiln, (5) Fixed chimney Bull's trench kiln, (6) Down-draught kiln and (8) Bull's trench kiln.

\section{Future Trends for BK Emissions}

A basic principle of the ABKs design is that the kilns should not emit polluting gases. Currently, studies on the pollution of gases emitted by a traditional BK are very detailed and specific, which supports the decision to change technology. Tabinda et al. [77] compared the concentration of pollutants and their level of dispersion in the atmosphere from the BKs plume using different types of fuels. In turn, Nasim and Sharif [78] raised the need for non-polluting kilns through their comparative study between a Bull's Trench Kiln (BTK) and an Induced Draft Zigzag Kiln (IDZZK). Here, they question themselves: Do ZZKs tend to be cleaner than BTKs? Will operating ZZKs generate any reasonable economic and social benefits? New technologies must improve the fluid dynamics of the gases inside the BK so that the emissions from the BK do not pollute. This is achieved through: (1) the use of fans, (2) mechanization of brick entry and removal and (3) automation of fuel injection [79-81]. Tasnim et al. [82] demonstrated through computational fluid dynamics (CFD) simulations that the Zigzag kiln (ZZK) is more efficient than the Fixed Chimney kilns (FCK), since in the ZZK, the swirling motion is created by turbulence. This "hot air" travels farther, so the mixture is uniform and appropriate. Therefore, the creation and propagation of the flame is good enough to use the fuel efficiently. Less energy is needed in this case. Therefore, in this case the emission in the ZZK is much lower than that of the FCK. 
On the other hand, in Mexico and Peru organic additives have been used, obtaining an alteration in the structure of the mixture resulting in a solid, permeable, resistant, moldable, recyclable composition and less contamination in the burning stage [76].

Finally, the aspects of fuel quality are detailed below, since it is also an important factor in reducing the emission of contaminating gases.

\subsection{Fuel Used in $B K$}

The fuel used in ABKs is of poor quality, i.e., (1) it does not have a uniform particle size, (2) it has fluctuating humidity, (3) it contains organic matter and (4) it is even supplemented by domestic solid waste. The BKs used in all countries consume a variety of fuels for their operation, including firewood, bagasse, rice husk and coal [83]. Many kilns also use a mixture of fuels. Although, some authors describe coal as the traditional fuel in brick firing $[84,85]$. In other cases, fuels are added separately and in others, they are pre-mixed. In addition, fuel may be added to the clay during the clay preparation process. The fuel mixed in the clay is often a low calorific fuel such as ash [86]. On the other hand, in Latin American brick manufacturing industry, the main source of fuel is biomass. For example, in Chile, waste wood or "lampazo" is used as fuel [87].

\section{Future Trends for Fuel Used in BK}

Currently, the artisanal brick industry has a fuel switch process due to (1) lower combustion costs, (2) organic waste near the production site and (3) lower pollutant emissions. It should be noted that the organic waste with the greatest energy potential is agricultural waste $[88,89]$. Zavaleta [90] researched the change from firewood to chestnut shells for Bolivia's artisan brick industry, since $70 \%$ of the world's chestnut production is in Bolivia. In addition, the exploitation of Brazil chestnut shells helps to stop the depredation of the Amazon rainforest. The chestnut shell used at the beginning of combustion process, along with implementation of fans, allows for a reduction of $32 \%$ in fuel consumption. Bahena et al. [91] shows the use of a mixture of coconut shells with firewood in the artisan brick sector of Guerrero (Mexico), due to the characteristics of the area's vegetation.

The global trend is for solid organic fuel to go through a torrefaction process and then an increase in density (pellets), because it is a viable energy variant for artisan brick producers, since they could make a stable contribution to community development with a significant social impact by creating new sources of employment. In addition, pellets contribute to the (1) use of non-polluting energy and (2) recycling of organic waste, which in many cases has no intended destination. Bhutto et al. [92] presents the pellets potential in Pakistan as renewable energy resources and examine the possibilities of adopting an efficient use of this biomass for brick kilns. Kpalo et al. [93] report that the artisan brick industry is a good example of the use of carbonized (charcoal) and non-carbonized (pellets) biomass briquettes.

\subsection{Energy Efficiency of $B K$}

The principal index for an energetic assessment is the Specific Energy Consumption (SEC), which is measured in $\mathrm{MJ} / \mathrm{kg}$. Widely varying data are found in the literature of SEC values for brick kilns $[51,85,94]$. This can be reasonably attributed to differences in the (1) fuel heating power, (2) size of bricks, (3) weight of bricks and (4) quality of fired bricks [25,52]. Weyant et al. [86] reported that a Bull's Trench Kiln (Hapur, India), a natural Draft zigzag (Greater Noida, India), a Bull's Trench Kiln (Kathmandu, Nepal), a forced Draft zigzag (Kathmandu, Nepal), a large Clamp (Sangli, India) and small Clamp (Pune, India) have an SEC of 1.17, 1.07, 1.17, 1.14, 1.33 and $1.90 \mathrm{MJ} / \mathrm{kg}$ brick, respectively.

Traditionally, some of the efficiency improvement measures, which were found to be effective included (1) adding roofs to clamps, (2) providing permanent walls that are insulated with mud and a biomass residue (such as rice husk), (3) increasing the height of the kilns, (4) enclosing the firebox and (5) adding a grate to the firebox [82]. Considerable energy saving has been reported by Barriga [95] when small pieces of wood were used and the burning rate was carefully controlled. 
Nowadays, the energy efficiency of industrial brick kiln is very knowing. Rahman and Kazi [79] reported that Tunnel kiln and Hybrid Hoffman kiln are energy-efficient brick kiln technologies. These kiln technologies have lower SEC and therefore burn less fuel and release fewer greenhouse gases (GHGs) per output unit. Additionally, energy-efficient technologies give operators more control over the fuel combustion process, which results in more complete carbonaceous fuel combustion and decreased emissions of black carbon and other PM. These technologies can provide financial returns through savings in fuel cost per output unit.

\section{Future Trends for Energy Efficiency of Brick Kiln}

The global trend is to make bricks with more energy-efficient processes. This leads to lower pollutant emissions, improved fuel quality, and reduced fuel consumption. Lloyd [96] studied the energy efficiency in clay brick manufacturing in South Africa. Studies were carried out on a variety of such kilns. For medium-sized producers, with a capacity of 30 million bricks per annum, a vertical shaft kiln appeared ideal. They required over $2 \mathrm{MJ} / \mathrm{kg}$, but this included the energy necessary to dry the green brick. Some consideration is also given to changes in the design of the standard brick, particularly the use of perforations within the brick. These improve the heat transfer during firing and require less energy per brick because they weigh less. Being lighter, they are also cheaper to transport than a solid brick of the same size. P.N. et al. [97] researched the reduction of the brick firing temperature in the kiln to about $600{ }^{\circ} \mathrm{C}$, thereby reducing the cost of production and making the entire process environment-friendly. This work presented a suitable alternative for the safe disposal of industrial debris such as quarry dust and glass powder by incorporating them as a partial substitute for river sand, which is one of the costliest constituents of clay brick and thereby further reducing the cost of production.

The technology of the future must ensure that BKs have a SEC $<1 \mathrm{MJ} / \mathrm{kg}$.

\subsection{Phenomenological Studies About Clay Brick Firing Process}

These researches are divided into chemical reactions and fluid dynamics during brick firing. Akinshipe and Kornelius [94] described in exact detail the six stages during clay brick firing process:

(1) Evaporation $\left(20-150{ }^{\circ} \mathrm{C}\right)$, slow heating stage where evaporation of the water that is added into the clay mixture during processing (free water). It is essential at this stage to maintain gradual increase in temperature to prevent the bricks from cracking, since the outer surface of the bricks will contract at a faster rate than inside the bricks, leading to cracking. An endothermic reaction is observed at this stage due to the loss of the free water.

(2) Dehydration $\left(149-650^{\circ} \mathrm{C}\right)$, in this stage burning out and breaking down the carbonaceous matter and carbonates, as well as the "combined water" occurs. Rapid heating may cause an atmosphere of steam to persist around and within the bricks, that produces discoloration or dark-colored, cored and bloated bricks, due to insufficient supply of oxygen within the bricks. An endothermic reaction is observed at this stage due to further release of water and carbonaceous matter.

(3) Oxidation (300-982 ${ }^{\circ} \mathrm{C}$ ), this stage depends on (a) the rate of heating, (b) the quantity of carbon present in the clay, (c) the amount of excess air available in the combustion chamber, (d) the density and (e) area to volume ratio of the clay bricks. In order to produce quality bricks, it is essential that any carbonaceous residue matter be combusted and all iron residues oxidized to its oxides at this stage. This could be achieved by: ensuring excess air of $50 \%$ or more is circulated within the combustion chamber; holding the temperature of oxidation at about $800-900{ }^{\circ} \mathrm{C}$ for a few days (3-4 days in some kilns); and keeping the $\mathrm{CO}_{2}$ level in the flue gas at $10 \%-12 \%$. An exothermic reaction is observed at this stage and is due to the oxidation of organic compounds and, subsequently, sulfide compounds in the clay material. This exothermic reaction is observed from $300{ }^{\circ} \mathrm{C}$ up to $450{ }^{\circ} \mathrm{C}$, and then an endothermic reaction sets in. This is attributed to the loss of water from the crystal structure of the mineral and a change in crystalline phase of the quartz from $\alpha$ to $\beta$ form. The carbonates decompose in heating to form oxides and $\mathrm{CO}_{2}$ : 


$$
\begin{aligned}
\mathrm{FeSO}_{3(\mathrm{~s})} & \rightarrow \mathrm{FeO}_{(\mathrm{s})}+\mathrm{CO}_{2(\mathrm{~s})} \\
\mathrm{MgSO}_{3(\mathrm{~s})} & \rightarrow \mathrm{MgO}_{(\mathrm{s})}+\mathrm{CO}_{2(\mathrm{~s})} \\
\mathrm{CaCO}_{3(\mathrm{~s})} & \rightarrow \mathrm{CaO}_{(\mathrm{s})}+\mathrm{CO}_{2(\mathrm{~s})}
\end{aligned}
$$

The loss of water is achieved without damage or shrinkage of the of the clay mineral lattice structure. The most likely compound to be formed during brick firing is calcium sulfate $\left(\mathrm{CaSO}_{4}\right)$, in a complex reaction proposed by Tourneret et al. [98], as follows:

$$
\begin{gathered}
9 \mathrm{CaCO}_{3(\mathrm{~s})}+9 \mathrm{SO}_{2(\mathrm{~g})} \rightarrow 6 \mathrm{CaSO}_{4(\mathrm{~s})}+\mathrm{CaSO}_{3(\mathrm{~s})}+2 \mathrm{CaS}_{(\mathrm{s})}+9 \mathrm{CO}_{2(\mathrm{~g})} \\
4 \mathrm{CaSO}_{3(\mathrm{~s})} \rightarrow 3 \mathrm{CaSO}_{4(\mathrm{~s})}+\mathrm{CaS}_{(\mathrm{s})} \\
\mathrm{CaS}_{(\mathrm{s})}+2 \mathrm{O}_{2(\mathrm{~g})} \rightarrow \mathrm{CaSO}_{4(\mathrm{~s})} \\
\mathrm{CaO}_{(\mathrm{s})}+\mathrm{SO}_{2(\mathrm{~g})}+3 \mathrm{CO}_{(\mathrm{g})} \rightarrow \mathrm{CaS}_{(\mathrm{s})}+3 \mathrm{CO}_{2(\mathrm{~g})}
\end{gathered}
$$

(4) Vitrification $\left(900-1316^{\circ} \mathrm{C}\right)$, the strength of the fired bricks is developed during vitrification, by sintering of clay particles and melting of the clay mass. The solid particles are coated with a liquid that, when cooled, forms a glassy solid and binds the particles together. The strength of the fired bricks depends on (a) the maximum temperature reached, (b) the duration of the vitrification stage or maximum temperature and (c) amount of fluxes (potash, soda, magnesia, lime and ferrous oxide) present in the clay. At this stage, a series of exothermic reactions are observed, due to the slow oxidation of sulfur compounds and possibly residual organic material, as well as formation of new crystalline phases.

(5) Flashing (1150-1316 $\left.{ }^{\circ} \mathrm{C}\right)$, holding the peak or finishing temperature for a period in order to impact the required color to the bricks by the addition of "un-combusted fuel" to the kiln.

(6) Cooling $\left(1316-20^{\circ} \mathrm{C}\right)$, this is the decrease of kiln temperature from peak to ambient temperature, lasting a few days ( $4-5$ days or more).

The research about the fluid dynamic behavior of the fluid inside the kiln allows for the improvement of (1) the distribution of the fluid inside the kiln, (2) the residence time, (3) the optimal distribution of the bricks and (4) the fuel consumption. The fluid dynamics of the fluid inside the brick kiln has been studied in tunnel kilns by means of 3D modeling and validated with experimental results; Almutari et al. [59] report the results of airflow in tunnel kilns using a 3D computational fluid dynamics (CFD) model. The numerical results demonstrated fluid flow malfunctions in tunnel kilns, including an intriguing phenomenon of long flow separation zone behind the brick setting. Tasnim et al. [82] evaluate the performance of Fixed Chimney kiln and Zigzag kiln through CFD simulation. CFD analysis helps to simulate the temperature profile of the brick kilns, the mass flow fractions of $\mathrm{CO}_{2}$ and NOx emissions at the outlet, and also the air velocity profile inside the kiln.

Future Trends about Phenomenological Studies

Currently, computational capacity allows for computational simulations of complex physical systems. The researches about the phenomenology of brick firing using computational simulations are very scarce. BK designs based on computational simulations foster collaboration among global engineering teams and increase data sharing to innovate product design and reduce development costs. The researches point to computational simulations that allow simultaneous analysis of (1) heat transfer, (2) fluid dynamics and (3) chemical reactions (combustion and firing). This will allow the results to be obtained closer to what actually happens during brick firing. These types of simulations depend on the computer capacity available in the research group. Bustos et al. [99] carried out this type of simulation for the elaboration of charcoal in a brick kiln, and their results provide important information for the improvements in the kiln operation and allow establishment of consistent initial 
conditions of temperature and heat flux for kinetics models for charcoal cooling in kilns. Alrahmani et al. [100] researched the effect of lattice setting density on fluid flow and convective heat transfer characteristics of bricks in Tunnel Kilns, using a 3D-computational fluid dynamics model with $\mathrm{k}-\omega$ turbulence model. The computational simulations allowed that the authors report the effect of setting density on flow uniformity, pressure drop, pumping power and convective heat transfer coefficients.

\section{Discussions and Conclusions}

Brick making is an ancient technology and the basic concept of brick kiln technology in developing countries has changed little over the past thousands of years. Bricks are made, dried, fired and cooled. Kilns first started in pits, and walls were then added. The addition of a chimney stack improved the air flow or draught of the kiln, thus burning the fuel more completely. Several variations have been invented over the years with varying degrees of efficiency and cost [61].

The technology transfer and skills to artisan brick-makers has been increasing over the past few years, but other challenges and barriers remain: (1) a mentality focused on maintaining cultural habit in traditional business practices and operations; (2) restricted access to financing to obtain preferential green credit lines to support investment costs; (3) lack of detailed knowledge of practices and costs of innovative operations; (4) environmental impact assessment requirements and process take longer than expected; and (5) adverse investment climate due to fluctuating financial situation, both locally and internationally. Therefore, we suggest that the authority promote "sustainable brick production" (SBP) through state policy. The SBP should be based on sustainable development actions, achieving a balance between the three main pillars: Social, Economy and Environment. In other words, actions that are socially accepted, activate the market and are without environmental impact. For example, (1) reduction of taxes for brick-makers who carried out innovations that allow reducing: polluting emissions, fuel consumption and process time; (2) education programs aimed at artisan brick-makers, about sustainable development and/or management of sustainable projects; (3) promote government innovation projects jointly executed by artisan brick-makers and researchers; and (4) publicity of SBP in the media. The impact of these suggestions will be a less polluting brick industry and a better quality of life for brick-makers.

Most of the future trends are towards improved combustion, both in terms of cost reduction and reduction of pollutant emissions. Good combustion in the ABK is achieved by correctly sizing the combustion chambers according to the type of fuel and the load to be processed. For example, a very small combustion chamber, fed with a lot of wood, may not receive enough air for a good burn, and thus generate a lot of soot and wasted energy. In addition, combustion must be controlled and the fuel feed must be as continuous as possible. On the other hand, using air injection by means of fans allows for (1) a reduction in burning time, (2) a decrease in fuel consumption by $30 \%$ and (3) an improvement in the quality of the product, due to the adequate supply of heat. The latter implies that the fans reduce the poor heat distribution problems in the furnace, avoid burning with yellowish flame and excessive soot generation, which are indicators of inefficient combustion due to lack of air and consequently energy loss. Obviously, the fans generate a consumption of electricity or liquid fuels but, on the contrary, does not represent a negative impact on production costs; it can be compensated by the low price of wood, the reduction in operating times, and improving the final quality of products [90].

The chemical reactions involved in the brick firing allow to visualize the generation of $\mathrm{CO}_{2}$ not only in the combustion but also in the chemical decomposition of the clay. Therefore, the brick industry will continue to emit $\mathrm{CO}_{2}$ despite all the technological advances that are adopted. This indicates that there should be a minimum forest area to compensate for these emissions.

The use of organic waste in the form of pellets improves the density (physical and energetic) of this waste. This leads to an improvement in the combustion process because the compaction of the organic waste, together with a previous roasting process, allows for a concentration of energy three times higher than that of the original waste $[92,101,102]$. 
Thermal insulation (proper sealing of walls, ceiling doors) can significantly increase the efficiency of ABK and contribute to greater energy savings. This can be seen in CFD simulations, as an adiabatic kiln, which is typically assumed in these simulations. Another aspect that can be highlighted in the CFD simulations is the distribution of the bricks in the BK, since an appropriate arrangement of the bricks helps to ensure efficient firing and improves the quality of the product, reducing fuel consumption and operating time by up to $5 \%$.

The researches about ABK should be oriented towards the adaptation of technologies for small producers, since only large brick producers have access to more thermally efficient and profitable processes. A great first step would be CFD simulations for small ABK.

Finally, we conclude that this article helps to develop a consistent scientific approach through discussing the state-of-the-art and future trends of the design and construction of artisan brick kilns. This article exposes issues that have not yet been massively researched, for example, fluid dynamics inside brick kilns. On the other hand, the elaboration of integral diagnostics to the artisan brick sector is of great importance, since it allows to identify the characteristics of the area where the changes will be implemented, to make adjustments to existing technology and to create strategies. In addition, the modification of the artisan brick activity is a cultural and professional challenge for the implementers of new technologies, where the management of such implementers has to take into account all socio-cultural barriers in order to achieve successful results. Therefore, management is the dimension that can make the environment and perception have positive effects on the adoption of technological change, since management includes planning actions aimed at shaping attitudes towards technology, based on the environment and the characteristics of the population. Then, the future technological trends must be more economical kilns and ensuring the reduction of environmental pollution. The new brick kiln designs that will emerge in the future must be justified with the fundamentals of heat transfer, fluid dynamics and chemical reactions, and not only with the experience transmitted from generation to generation.

Author Contributions: Conceptualization, H.V., J.F. and J.V.; methodology, H.V. and J.V.; software, G.F. and M.H.; validation, H.V., and G.F.; formal analysis, H.V.; investigation, H.V.; resources, J.F.; data curation, H.V.; writing-original draft preparation, H.V.; writing-review and editing, G.F. and M.H.; visualization, M.H.; supervision, H.V.; project administration, J.F.; funding acquisition, J.F. All authors have read and agreed to the published version of the manuscript.

Funding: This research "Transferencia innovación sustentable del proceso de fabricación de ladrillos industrializados en la Región del Maule" was funded by FNDR of the Government of the Maule Region, grant number Fondo de Innovación para la Competitividad (FIC)/40.001.167-0, and the APC was funded by FNDR of the Government of the Maule Region, grant number Fondo de Innovación para la Competitividad (FIC)/40.001.167-0.

Acknowledgments: The authors would like to acknowledge the Government of the Maule Region and Universidad Catolica del Maule.

Conflicts of Interest: The authors declare no conflict of interest.

\section{References}

1. Taffese, W.Z.; Abegaz, K.A. Embodied energy and $\mathrm{CO}_{2}$ emissions of widely used building materials: The ethiopian context. Buildings 2019, 9, 136. [CrossRef]

2. Pacheco-Torgal, F.; Jalali, S. Earth construction: Lessons from the past for future eco-efficient construction. Constr. Build. Mater. 2012, 29, 512-519. [CrossRef]

3. Duggal, S.K. Building Materials; Routledge: London, UK, 2017.

4. Naveen, S. Production and Marketing Network Chain of Brick Kiln Product: A Case Study of Hyderabad City. Int. J. Manag. Value Supply Chain 2016, 7, 27-37. [CrossRef]

5. Mitra, D.; Valette, D. Environment, Human Labour, and Animal Welfare: Unveiling the Full Picture of South Asia's Brick Kilns and Building the Blocks for Change; International Labour Office, The Brooke Hospital for Animals, The Donkey Sanctuary, ILO: Geneva, Switzerland, 2017. 
6. Corporation Bank. Setting Up Energy Efficient Brick Kiln for the Production of Resource Efficient Bricks; Model Project Report; Punjab State Council for Science \& Technology, Chandigarh University: Punjab, India, 2010.

7. Report on Identification of Strategies for Technology Conversion in Latin America. Available online: http://www.redladrilleras.net/apps/manual_ccac (accessed on 10 August 2020).

8. Darain, K.M.; Jumaat, M.Z.; Islam, A.S.; Obaydullah, M.; Iqbal, A.; Adham, M.I.; Rahman, M.M. Energy efficient brick kilns for sustainable environment. Desalin. Water Treat. 2016, 57, 105-114. [CrossRef]

9. Tranfield, D.; Denyer, D.; Smart, P. Towards a methodology for developing evidence-informed management knowledge by means of systematic review. Br. J. Manag. 2003, 14, 207-222. [CrossRef]

10. Mardani, A.; Zavadskas, E.K.; Govindan, K.; Senin, A.A.; Jusoh, A. VIKOR technique: A systematic review of the state of the art literature on methodologies and applications. Sustainability 2016, 8, 37. [CrossRef]

11. Kamal, A.; Malik, R.N.; Martellini, T.; Cincinelli, A. Cancer risk evaluation of brick kiln workers exposed to dust bound PAHs in Punjab province (Pakistan). Sci. Total Environ. 2014, 493, 562-570. [CrossRef]

12. Kamal, A.; Syed, J.H.; Li, J.; Zhang, G.; Mahmood, A.; Malik, R.N. Profile of atmospheric PAHs in Rawalpindi, Lahore and Gujranwala districts of Punjab province (Pakistan). Aerosol Air Qual. Res. 2016, 16, 1010-1021. [CrossRef]

13. Kail, O. Brick Kiln. U.S. Patent 440041. Available online: https://patents.google.com/patent/US440041A/en (accessed on 15 March 2020).

14. Anonymous. Butterley's new style Brick Kiln. Refract. J. 1975, Jul-A, 17.

15. Hammond, M.D.P. Brick Kilns: An Illustrated Survey. Ind. Archaeol. Rev. 1977, 1, 171-192. [CrossRef]

16. Almond, P.; Cheyney, A.; Moss, H. The formation and extraction of landfill gas and its use on a brick kiln. Trans. J. Br. Ceram. Soc. 1983, 82, 48-50.

17. Prasertsan, S.; Theppaya, T.; Prateepchaikul, G.; Kirirat, P. Development of an energy-efficient brick kiln. Int. J. Energy Res. 1997, 21, 1363-1383. [CrossRef]

18. Bhanarkar, A.D.; Gajghate, D.G.; Hasan, M.Z. Assessment of air pollution from small scale industry. Environ. Monit. Assess. 2002, 80, 125-133. [CrossRef] [PubMed]

19. Budhwar, R.; Bihari, V.; Mathur, N.; Srivastava, A.; Kumar, S. DNA-protein crosslinks as a biomarker of exposure to solar radiation: A preliminary study in brick-kiln workers. Biomarkers 2003, 8, 162-166. [CrossRef]

20. Singh, D.P. Women workers in the brick Kiln industry in Haryana, India. Indian J. Gend. Stud. 2005, $12,83-97$. [CrossRef]

21. Singh, A.L.; Asgher, M.S. Impact of brick kilns on land use/landcover changes around Aligarh city, India. Habitat Int. 2005, 29, 591-602. [CrossRef]

22. Pandhija, S.; Rai, A.K. Screening of brick-kiln area soil for determination of heavy metal Pb using LIBS. Environ. Monit. Assess. 2009, 148, 437-447. [CrossRef]

23. Ahmad, I.; Khan, M.I.; Khan, H.; Ishaq, M.; Khan, R.; Gul, K.; Ahmad, W. Influence of waste brick kiln dust on pyrolytic conversion of polypropylene in to potential automotive fuels. J. Anal. Appl. Pyrolysis 2017, 126, 247-256. [CrossRef]

24. Khan, M.W.; Ali, Y.; De Felice, F.; Salman, A.; Petrillo, A. Impact of brick kilns industry on environment and human health in Pakistan. Sci. Total Environ. 2019, 678, 383-389. [CrossRef]

25. Weyant, C.; Kumar, S.; Maithel, S.; Thompson, R.; Baum, E.; Floess, E.; Bond, T. Brick Kiln Measurement Guidelines: Emissions and Energy Performance; Climate and Clean Air Coalition; Civil \& Environmental Engineering \& Greentech Knowledge Solutions Pvt. Ltd.; University of Illinois at Urbana-Champaign: Urbana/Champaign, IL, USA, 2016. Available online: https://www.ccacoalition.org/ (accessed on 13 April 2020).

26. Red de Ladrilleras. Manual de Hornos Eficientes en la Industria Ladrillera. Programa de eficiencia energética en Ladrilleras de America Latina para mitigar el cambio climático. 2015. Available online: http://www.redladrilleras.net (accessed on 4 May 2020).

27. Swisscontact. Manual de Capacitación Sector Ladrillero en América Latina, 1st ed.; Climate and Clean Air Coalition: Lima, Peru, 2016. Available online: https://www.swisscontact.org (accessed on 12 June 2020).

28. Swisscontact. Cartilla de Producción Más Limpia para Ladrilleras Artesanales. Available online: https: //www.swisscontact.org (accessed on 12 June 2020).

29. Navarro, A. Factibilidad Técnica de Mejorar el Revestimiento de Muros de Fábrica de Cocción de Ladrillos, en su Producción. Caso Productores Artesanales de la Comuna de Linares. Bachelor's Thesis, Universitat Politécnica de Catalunya, Barcelona, Spain, 2016. 
30. Fuch, L.; Heim, T.; Zürcher, D. Energy Efficiency and Emissions of Artisanal Brick Kilns in Peru. Bachelor's Thesis, University of Applied Sciencies and Arts Northwestern Switzerland, Delemont, Switzerland, 2016.

31. Ortínez, A.; Gavilan, A. Cuantificación de las emisiones de contaminantes en un horno fijo tradicional y un horno ecológico-dgo. In Estudios Ambientales de las Emisiones Vehiculares, Produccion de Ladrillo, Exposicion Personal a Contaminantes, Monitoreo de la Calidad del Aire, Hidrocarburos y Particulas, en la Ciudad Victoria de Durango, Durango; Instituto Nacional de Ecologia y Cambio Climatico: Durango, Mexico, 2016.

32. Amboro, J.L.; Wahyuningsih, N.; Nurcahyanti, D. Traditional ceramic kiln development model. In Proceedings of the 2nd International Conference on Creative Media, Design \& Technology (REKA2016), Penang, Malaysia, 26-27 September 2016.

33. Ramírez, J.R.; Nava, F.D.; Alvarez, C.M.; Lagunas, L.M.; Lescas, M.A. Perfiles de temperatura en un horno ladrillero. Rev. Mex. Ing. Química 2004, 3, 209-217.

34. Jenkins, M. The Technical Development of Brickwork in Scotland, 1700-1900. Ph.D. Thesis, University of Dundee, Dundee, Scotland, UK, 2016.

35. Piñeros, L.; Rodríguez, D. Aplicación del Modelo ISC Aermod para Determinar los Niveles de Incumplimiento de la Norma de Calidad del Aire para Material Particulado (PM10), en el Sector Industrial de Patio Bonito en el Municipio de Nemocón (Cundinamarca); Ingeniería Ambiental y Sanitaria, Universidad de la Salle: Bogotá, Colombia, 2008; Available online: https://ciencia.lasalle.edu.co/ing_ambiental_sanitaria/329 (accessed on 23 June 2020).

36. Maquera, Y.L. Contaminantes atmosféricos emitidos por hornos ladrilleros artesanales y su efecto en la salud humana y la vegetación. In 6ta Jornada Cientifica de Estudiantes-FIA; Universidad Peruana Unión: Lima, Peru, 2017.

37. Areiza, R. Modelado, Simulación y Desarrollo de un Análisis de Eficiencia Energética en un Horno Ladrillero Tipo Bóveda en Condiciones de Estado Estacionario. Ph.D. Thesis, Universidad Tecnológica de Pereira, Pereira, Colombia, 2014.

38. Abir, A.H.; Sarker, A.H. Role of Laws to Control Brick Manufacturing and Kiln Establishment in Bangladesh: Scope of Alternative Bricks. VNU J. Sci. Earth Environ. Sci. 2019, 35, 1. [CrossRef]

39. Parastiwi, A.; Makhfufah, D.T. Studi Komparasi Pengontrolan Suhu Down-Draft Kiln pada Industri Keramik Rakyat Dinoyo dengan Logika Fuzzy dan Kontrol PID. Pros. Semin. Nas. Teknol. Elektro Terap. 2018, 2, 169-174.

40. Rajarathnam, U.; Athalye, V.; Ragavan, S.; Maithel, S.; Lalchandani, D.; Kumar, S.; Baum, E.; Weyant, C.; Bond, T. Assessment of air pollutant emissions from brick kilns. Atmos. Environ. 2014, 98, 549-553. [CrossRef]

41. Zavala, M.; Molina, L.; Maiz, P.; Monsivais, I.; Chow, J.; Watson, J.; Munguia, J.; Cardenas, B.; Fortner, E.; Herndon, S.; et al. Black carbon, organic carbon, and co-pollutant emissions and energy efficiency from artisanal brick production in Mexico. Atmos. Chem. Phys. 2018, 18. [CrossRef]

42. Luján, M.; Guzmán, D. Design, Construction and Evaluation of a furnace (MK3) for firing craft bricks. Acta Nova 2015, 7, 165-193.

43. Bustamante, V.; Carrillo, A.; Gonzalez, H.; Ramirez, R.G.; Corral, J.; Garza, F. Evaluation of a charcoal production process from forest residues of Quercus sideroxyla Humb., \& Bonpl. in a Brazilian beehive kiln. Ind. Crop. Prod. 2013, 42, 169-174. [CrossRef]

44. Lin, J.C.M. Development of a high yield and low cycle time biomass char production system. Fuel Process. Technol. 2006, 87, 487-495. [CrossRef]

45. Díaz, J.I.; Molina, J.S.; Prato, J.G. Energy-Environmental diagnosis of the ceramic sector companies in the metropolitan area of Cucuta, Norte de Santander, Colombia. Key Eng. Mater. 2016, 663, 133-139. [CrossRef]

46. Saboya, F., Jr.; Xavier, G.C.; Alexandre, J. The use of the powder marble by-product to enhance the properties of brick ceramic. Constr. Build. Mater. 2007, 21, 1950-1960. [CrossRef]

47. Lis, T.; Nowacki, K. Determination of physical and chemical properties of electric arc furnace dusts for the purposes of their utilization. Sil. Univ. Technol. 2012, 83, 842-851. [CrossRef]

48. Maheshwari, H.; Jain, K. Carbon footprint of bricks production in fixed chimney Bull's trench kilns in India. Indian J. Sci. Technol. 2017, 10, 1-11. [CrossRef]

49. Le Brun, N.; Markides, C.N. Framework for the Energetic Assessment of South and South-East Asia Fixed Chimney Bull's Trench Kiln. MATEC Web Conf. 2016, 68, 11001. [CrossRef]

50. Red de Ladrilleras. Factsheet about Brick/Tiles Kiln Technologies in Latin America: Cedan kiln (semi-continuous). Climate \& Clean Air Coalition. Available online: https://www.ccacoalition.org/en/ resources/bricktile-kiln-technologies-latin-america-factsheet (accessed on 7 July 2020). 
51. Nepal, S.; Mahapatra, P.S.; Adhikari, S.; Shrestha, S.; Sharma, P.; Shrestha, K.L.; Pradhan, B.B.; Puppala, S.P. A Comparative Study of Stack Emissions from Straight-Line and Zigzag Brick Kilns in Nepal. Atmosphere 2019, 10, 107. [CrossRef]

52. Ramos, E.A. Diseño y Cálculo de Horno Continuo de Cámaras Múltiples en Fábrica de Ladrillos Cerámicos Sol del Norte; Ingeniería Mecánica y Eléctrica; Universidad Nacional Pedro Ruiz Gallo: Lambayeque, Peru, 2020; Available online: http://repositorio.unprg.edu.pe/handle/UNPRG/8151 (accessed on 7 July 2020).

53. Gomaa, H. Charcoal production from agricultural residues (Egypt). In Proceedings of the Expert Consultation on the Utilization of Agricultural Residues, Cairo, Egypt, 6-8 June 2004.

54. Fontalvo, E.; Gutíerrez, E. Diseño de un Horno para Cocción de Ladrillos Refractarios en una Empresa del Sector Ladrillero; Universidad Autonoma del Caribe: Barranquilla, Colombia, 2014.

55. Nizhegorodov, A. Electric Modular-Trigger Kiln with an Energy Recuperation System for Firing Vermiculte Concentrates. Refract. Ind. Ceram. 2016, 56, 470-475. [CrossRef]

56. Xiao, H.; Cheng, Q.; Liu, M.; Li, L.; Ru, Y.; Yan, D. Industrial disposal processes for treatment of polychlorinated dibenzo-p-dioxins and dibenzofurans in municipal solid waste incineration fly ash. Chemosphere 2020, 243. [CrossRef] [PubMed]

57. Filkoski, R.V.; Petrovski, I.J.; Gjurchinovski, Z. Energy optimization of vertical shaft kiln operation in the process of Dolomite calcination. Therm. Sci. 2018, 22, 2123-2135. [CrossRef]

58. Refaey, H.A.; Abdel-Aziz, A.A.; Salem, M.R.; Abdelrahman, H.E.; Al-Dosoky, M.W. Thermal performance augmentation in the cooling zone of brick tunnel kiln with two types of guide vanes. Int. J. Therm. Sci. 2018, 130, 264-277. [CrossRef]

59. Almutairi, J.H.; Alrahmani, M.A.; Almesri, I.F.; Abou-Ziyan, H.Z. Effect of fluid channels on flow uniformity in complex geometry similar to lattice brick setting in tunnel kilns. Int. J. Mech. Sci. 2017, 134, 28-40. [CrossRef]

60. Oba, R.; Possamai, T.; Nicolau, V. Thermal analysis of a tunnel kiln used to produce roof tiles. Appl. Therm. Eng. 2014, 63, 59-65. [CrossRef]

61. Habla zig-zag kilns (HZZK). The Kiln Process: Overview of the Brick Making Process. Habla Zig-Zag Kilns. 2019. Available online: https://www.hablakilns.com (accessed on 4 May 2020).

62. Abou-Ziyan, H.Z.; Almesri, I.F.; Alrahmani, M.A.; Almutairi, J.H. Convective Heat Transfer Coefficients of Multifaceted Longitudinal and Transversal Bricks of Lattice Setting in Tunnel Kilns. J. Therm. Sci. Eng. Appl. 2018, 10. [CrossRef]

63. Hüsing, R. Continuous reduction firing in the tunnel kiln. Ziegelind. Int. Brick Tile Ind. Int. 2018, 2, $42-47$.

64. Bhat, M.S.; Afeefa, Q.S.; Ashok, K.P.; Bashir, A.G. Brick kiln emissions and its environmental impact: A Review. J. Ecol. Nat. Environ. 2014, 6, 1-11. [CrossRef]

65. Luby, S.P.; Biswas, D.; Gurley, E.S.; Hossain, I. Why highly polluting methods are used to manufacture bricks in Bangladesh? Energy Sustain. Dev. 2015, 28, 68-74. [CrossRef]

66. Ravankhah, N.; Mirzaei, R.; Masoum, S. Determination of heavy metals in surface soils around the brick kilns in an arid region, Iran. J. Geochem. Explor. 2017, 176, 91-99. [CrossRef]

67. Skinder, B.M.; Sheikh, A.Q.; Pandit, A.K.; Ganai, B.A.; Kuchy, A.H. Effect of brick kiln emissions on commonly used vegetables of Kashmir valley. Food Sci. Nutr. 2015, 3, 604-611. [CrossRef]

68. Stockwell, C.E.; Christian, T.J.; Goetz, J.D.; Jayarathne, T.; Bhave, P.V.; Praveen, P.S.; Adhikari, S.; Maharjan, R.; DeCarlo, P.F.; Stone, E.A.; et al. Nepal Ambient Monitoring and Source Testing Experiment (NAMaSTE): Emissions of trace gases and light-absorbing carbon from wood and dung cooking fires, garbage and crop residue burning, brick kilns, and other sources. Atmos. Chem. Phys. 2016, 16, 11043-11081. [CrossRef]

69. Akinshipe, O.; Kornelius, G. Quantification of atmospheric emissions and energy metrics from simulated clamp kiln technology in the clay brick industry. Environ. Pollut. 2018, 236, 580-590. [CrossRef]

70. Arif, M.; Kumar, R.; Kumar, R.; Zusman, E.; Gourav, P. Corrigendum to "Ambient black carbon, PM2.5 and PM10 at Patna: Influence of anthropogenic emissions and brick kilns". Sci. Total Environ. 2018, 644, 1649. [CrossRef]

71. Awasthi, A.; Agarwal, R.; Mittal, S.K.; Singh, N.; Singh, K.; Gupta, P.K. Study of size and mass distribution of particulate matter due to crop residue burning with seasonal variation in rural area of Punjab, India. J. Environ. Monit. 2011, 13, 1073-1081. [CrossRef] [PubMed] 
72. Fan, N.; Lamson, A.D.; Anenberg, S.C.; Wesson, K.; Risley, D.; Hubbell, B.J. Estimating the National Public Health Burden Associated with Exposure to Ambient PM2.5and Ozone. Risk Anal. 2012, 32, 81-95. [CrossRef] [PubMed]

73. Kampa, M.; Castañas, E. Human health effects of air pollution. Environ. Pollut. 2008, 151, 362-367. [CrossRef] [PubMed]

74. Nath, A.J.; Lal, R.; Das, A.K. Fired Bricks: $\mathrm{CO}_{2}$ Emission and Food Insecurity. Glob. Chall. 2018, 2, 1700115. [CrossRef] [PubMed]

75. Sun, F.; Dai, Y.; Yu, X. Air pollution, food production and food security: A review from the perspective of food system. J. Integr. Agric. 2017, 16, 2945-2962. [CrossRef]

76. Febres, T. Alternativa de Solución a la Problemática Ambiental Producida por las Ladrilleras Artesanales en Arequipa. Master's Thesis, Universidad Nacional de San Agustin, Arequipa, Peru, 2017.

77. Tabinda, A.B.; Anjum, Z.; Yasar, A.; Rasheed, R.; Mahmood, A.; Iqbal, A. Determination and dispersion of pollutants from different fuel types used in brick kilns by using Gaussian's plume model. Energy Sources Part A Recovery Util. Environ. Eff. 2019, 41, 1022-1028. [CrossRef]

78. Nasim, S.; Sharif, F. To adopt, or not to adopt, 'why' is the question: A case for clean kiln technologies in developing countries. J. Clean. Prod. 2020, 257, 120553. [CrossRef]

79. Rahman, S.; Kazi, S.M. Assessment of Brick Kiln Technologies of Bangladesh. Master's Thesis, Institute of Appropriate Technology (IAT), Bangladesh University of Engineering and Technology (BUET), Ramna, Bangladesh, 30 March 2019.

80. Khaliquzzaman, M.; Harinath, A.S.; Ferdousi, S.A.; Khan, S.M. Thirty Years' Quest for Emission Reduction and Energy Efficiency Improvement of Brick Kilns in Bangladesh. Int. J. Environ. Monit. Anal. 2020, 8, 11. [CrossRef]

81. Haque, N. Technology mandate for greening brick industry in Bangladesh: A policy evaluation. Clean Technol. Environ. Policy 2017, 19, 319-326. [CrossRef]

82. Tasnim, F.; Istiaque, F.; Morshed, A.; Ahmad, M. A CFD investigation of conventional brick kilns. In Proceedings of the AIP Conference, 8th BSME International Conference on Thermal Engineering; AIP Publishing LLC: Dhaka, Bangladesh, 2019; Volume 2121, p. 040006. [CrossRef]

83. Bhattacharya, S.C.; Attalage, R.A.; Augustus, M.L.; Amur, G.Q.; Salam, P.A.; Thanawat, C. Potential of biomass fuel conservation in selected Asian countries. Energy Convers. Manag. 1999, 40, 1141-1162. [CrossRef]

84. Lakho, N.A.; Zardari, M.A. Structural Properties of Baked Clay Bricks Fired with Alternate Fuels. Engineering 2016, 8, 676-683. [CrossRef]

85. Mancuhan, E.; Kucukada, K. Optimization of fuel and air use in a tunnel kiln to produce coal admixed bricks. Appl. Therm. Eng. 2006, 26, 1556-1563. [CrossRef]

86. Weyant, C.; Kumar, S.; Maithel, S.; Thompson, R.; Floess, E.; Ravi, A.; Adhikari, S.; Gautam, S.; Shrestha, S.; Baum, E.; et al. Emissions and Energy Performance in South Asian Brick Kilns: Measurement Report 2016; University of Illinois Urbana-Champaign: Champaign, IL, USA, 2016.

87. Brevis-Díaz, G.; Salinas-Salas, A. Aplicaciones Tecnológicas al Proceso de Fabricación Artesanal de Ladrillos para la Mejora de sus Emisiones Atmosféricas en la Comuna de Cauquenes, Región del Maule. Master's Thesis, Universidad de Talca, Talca, Chile, 2016.

88. Osueke, C.; Olayanju, T.; Ezugwu, C.; Onokwai, A.; Ikpotokin, I.; Uguru-Okorie, D.; Nnaji, F. Comparative Calorific Evaluation of Biomass Fuel and Fossil Fuel. International. J. Civ. Eng. Technol. 2018, 9, 1576-1590.

89. Tan, F.; He, L.; Zhu, Q.; Wang, Y.; Hu, G.; He, M. Characterization of Different Types of Agricultural Biomass and Assessment of Their Potential for Energy Production in China. BioResources 2019, 14, 6447-6464.

90. Zavaleta, P. Analysis of productive and environmental impacts of the implementation of fans and fuel switching in artisan brick kilns in Riberalta, Beni. Acta Nova 2018, 8, 679-699.

91. Bahena, F.; Corral, A.; Juárez, A.; Rosas, J.; Reyes, M.; Bedolla, R. Estudio socioambiental del sector ladrillero artesanal en el municipio de Coyuca de Benítez, Guerrero. Cienc. Front. 2019, 16, 7-19.

92. Bhutto, A.W.; Bazmi, A.A.; Karim, S.; Abro, R.; Mazari, S.A.; Nizamuddin, S. Promoting sustainability of use of biomass as energy resource: Pakistan's perspective. Environ. Sci. Pollut. Res. 2019, 26, 29606-29619. [CrossRef] [PubMed]

93. Kpalo, S.; Zainuddin, M.; Manaf, L.; Roslan, A. A Review of Technical and Economic Aspects of Biomass Briquetting. Sustainability 2020, 12, 4609. [CrossRef] 
94. Akinshipe, O.; Kornelius, G. Chemical and thermodynamic processes in clay brick firing technologies and assosciated atmospheric emissions metrics-a review. J. Pollut. Eff. Cont. 2017, 5. [CrossRef]

95. Barriga, A.; Duque, J.; Pincay, G.; Marcial, J.; Moreina, E. Study of the Use of Fuelwood in Brickmaking Industries in Guayaquil, Ecuador. Available online: http://biblioteca.olade.org/cgi-bin/koha/opac-detail.pl? biblionumber $=9937$ (accessed on 25 July 2020).

96. Lloyd, P. Energy efficiency in claybrick manufacture in South Africa. In Proceedings of the 2016 International Conference on the Industrial and Commercial Use of Energy (ICUE), Cape Town, South Africa, 16-17 August 2016.

97. Peter, C.; Mohan, K.; Greens, S.; George, S. Energy efficient production of clay bricks using industrial waste. Heliyon 2018, 4, 1-12. [CrossRef]

98. Tourneret, L.; Berger, F.; Mavon, C.; Chambaudet, A. Efflorescence-study of the formation of calcium sulphate during firing of ceramic ware. ZI Int. 1999, 52, 15-25.

99. Bustos, J.; Martins, M.; Carneiro, A.; Freitas, A.; Barbosa, R. Thermal inertia effects of the structural elements in heat losses during the charcoal production in brick kilns. Fuel 2018, 226, 508-515. [CrossRef]

100. Alrahmani, M.A.; Almesri, I.F.; Abou-Ziyan, H.Z.; Almutairi, J.H. Effect of lattice setting density on fluid flow and convective heat transfer characteristics of bricks in tunnel kilns. J. Therm. Sci. Eng. Appl. 2020, 12, 1-27. [CrossRef]

101. Whittaker, C.; Shield, I. Factors affecting wood, energy grass and straw pellet durability-A review. Renew. Sustain. Energy Rev. 2017, 71, 1-11. [CrossRef]

102. Cao, L.; Yuan, X.; Li, H.; Li, C.; Xiao, Z.; Jiang, L.; Huang, B.; Xiao, Z.; Chen, X.; Wang, H.; et al. Complementary effects of torrefaction and co-pelletization: Energy consumption and characteristics of pellets. Bioresour. Technol. 2015, 185, 254-262. [CrossRef] [PubMed]

(C) 2020 by the authors. Licensee MDPI, Basel, Switzerland. This article is an open access article distributed under the terms and conditions of the Creative Commons Attribution (CC BY) license (http://creativecommons.org/licenses/by/4.0/). 